\title{
Interaction of Helicobacter pylori and its fatty acids with parietal cells and gastric $\mathrm{H}^{+} / \mathrm{K}^{+}$-ATPase
}

\author{
W Beil, C Birkholz, S Wagner, K-F Sewing
}

\begin{abstract}
Helicobacter pylori and the fatty acids produced by this organism were compared for their acid inhibitory activity in isolated parietal cells and their interaction with gastric $\mathrm{H}^{+} / \mathrm{K}^{+}$-ATPase. $H$ pylori (intact organisms, sonicates, methanolic extracts, and extracts from culture medium) and the fatty acids cis 9,10-methyleneoctadecanoic acid and tetradecanoic acid inhibited at fairly high concentrations histamine- and dibutyryl cyclic adenosine monophosphate stimulated acid production in isolated parietal cells, dissipated (with a slow onset) the $\mathrm{H}^{+} / \mathrm{K}^{+}$-ATPase created $\mathrm{H}^{+}$gradient in gastric membrane vesicles, and inhibited $\mathrm{H}^{+} / \mathrm{K}^{+}$-ATPase activity in a concentration dependent manner. The inhibitory potency of $H$ pylori and the fatty acids in relation to $\mathrm{H}^{+} / \mathrm{K}^{+}$-ATPase depended on the amount of membrane protein. Bovine serum albumin prevented enzyme inhibition and proton dissipation from gastric vesicles. The data indicate that H pylori establishes its antisecretory action in parietal cells by blocking $\mathrm{H}^{+} / \mathrm{K}^{+}$-ATPase activity and also by $\mathbf{a}$ detergent action at the apical parietal cell membrane. The fatty acids cis 9,10-methyleneoctadecanoic acid and tetradecanoic acid are probably the acid inhibitory factors secreted by $\boldsymbol{H}$ pylori. (Gut 1994; 35: 1176-1180)
\end{abstract}

Acute infection with Helicobacter pylori is associated with reduced gastric acidity. This has been observed during serial experiments in man and after self infection. ${ }^{2}$ Possible mechanisms by which $H$ pylori causes hypochlorhydria include: (i) local immune response with release of acid inhibitory cytokines ${ }^{3}$ and (ii) release of a bacterial protein which inhibits parietal cell activity. ${ }^{4}$

In addition to hexadecanoic acid (C 16:0) and octadecanoic acid (C 19:0), $H$ pylori produces unusual fatty acids such as tetradecanoic acid (C 14:0) and cis 9,10-methy-

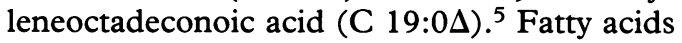
are known to inhibit the gastric proton pump, $\mathrm{H}^{+} / \mathrm{K}^{+}$-ATPase. ${ }^{6}$ In this report we have studied the effects of $H$ pylori and different fatty acids produced by this organism on acid production in isolated guinea pig parietal cells and their reaction pathway with purified pig $\mathrm{H}^{+} / \mathrm{K}^{+}$-ATPase.

\section{Methods \\ H PYLORI CULTURE}

The three isolates of $H$ pylori used in this study were obtained from antral mucosal biopsy specimens. Isolates were grown on $H$ pylori-selective agar plates (Skirrow's medium) or in $20 \mathrm{ml}$ brucella broth medium supplemented with $2.5 \%$ heat inactivated fetal calf serum (FCS) in glass Erlenmeyer flasks at $37^{\circ} \mathrm{C}$ for three days in a microaerophilic atmosphere.

Intact bacteria, sonicates, methanolic bacterial extracts, and extracts from bacterial culture medium were used. Intact bacteria were harvested in phosphate buffered saline solution, standardised to an $\mathrm{OD}_{600}$ of 1.0 , which is equivalent to about $1.5 \times 10^{8}$ colony forming units $/ \mathrm{ml}$, and then concentrated 100 fold by centrifugation. For sonicates, bacterial suspensions (in $20 \mathrm{mM}$ Tris/ $\mathrm{HCl}$ buffer, $\mathrm{pH} 7 \cdot 0$ ) were sonicated on ice (power: $50 \mathrm{~W}$ ) in six consecutive treatments lasting 30 seconds. Bacterial extracts were obtained by stirring $10^{10}$ bacteria in $1 \mathrm{ml}$ methanol for one hour at $4^{\circ} \mathrm{C}$. Remaining cell debris was separated from the extract by centrifugation (10000 $\mathrm{g}$ for five minutes). Bacterial culture medium was extracted with an equal volume of a chloroform/methanol solution, dried under a stream of $\mathrm{N}_{2}$, and then redissolved in $1 \mathrm{ml}$ methanol.

PARIETAL CELL ISOLATION AND ENRICHMENT AND MEASUREMENT OF ACID PRODUCTION Guinea pig parietal cells were isolated by collagenase and pronase digestion and enriched to about $80 \%$ purity by the elutriation technique. ${ }^{7}$ Acid production in parietal cells was monitored by the $\left[{ }^{14} \mathrm{C}\right]-$ aminopyrine uptake technique. Parietal cells $\left(5 \times 10^{5}\right.$ cells) were preincubated for 20 minutes at $22^{\circ} \mathrm{C}$ in $1 \mathrm{ml}$ buffer medium (pH 7.4) containing 8.3 $\mu \mathrm{M}$ aminopyrine and the agents to be tested. The buffer composition was $(\mathrm{mM}): \mathrm{NaCl}(70), \mathrm{NaHCO}_{3}(20)$, $\mathrm{NaH}_{2} \mathrm{PO}_{4}(0 \cdot 5), \mathrm{Na}_{2} \mathrm{HPO}_{4}(1 \cdot 0)$, HEPES (50), $\mathrm{CaCl}_{2}(1 \cdot 0), \mathrm{MgCl}_{2}(1 \cdot 5)$ and glucose (11). Acid production was initiated by histamine $(100 \mu \mathrm{M})$ or by the intracellular transmitter analogue dibutyryl cyclic adenosine monophosphate (AMP) (dbcAMP, $1 \mathrm{mM}$ ). After 40 minutes incubation at $37^{\circ} \mathrm{C}$, the cells were separated from the medium by centrifugation through silicon oil and the radioactivity of intracellularly trapped aminopyrine was counted.

Departments of and Gastroenter Medizinische Hannover, Germany W Beil

C Birkholz
} 


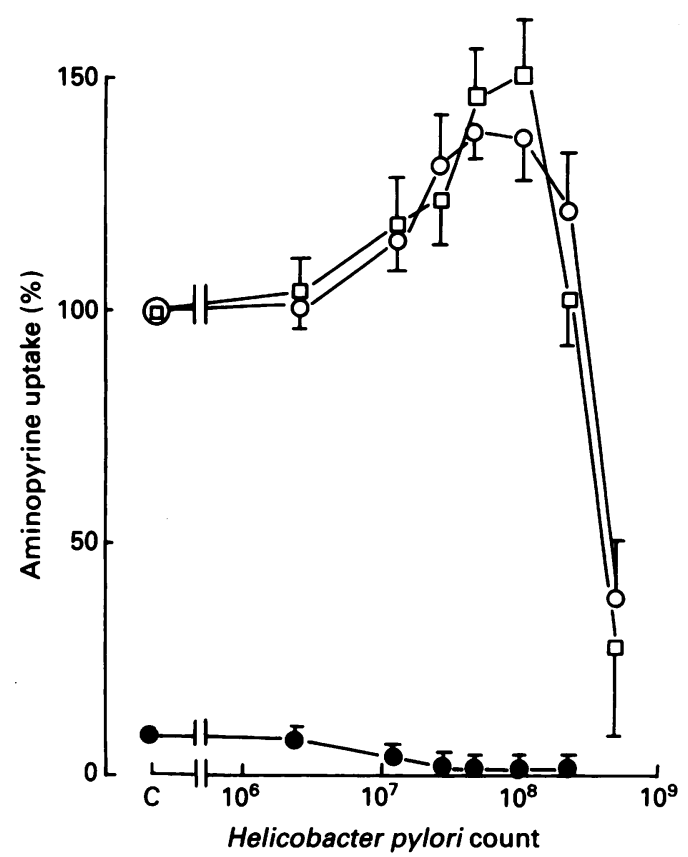

Figure 1: The effect of increasing Helicobacter pylori concentrations on basal ( $\bullet$, histamine (O), and dbcAMP () stimulated aminopyrine uptake in isolated and enriched guinea pig parietal cells. Parietal cells were treated for 20 minutes at $22^{\circ} \mathrm{C}$ with the indicated amounts of $\mathrm{H}$ pylori. Basal, histamine $(100 \mu M)$, and dbcAMP (1 mM) stimulated aminopyrine uptake were then determined after 40 minutes incubation at $37^{\circ} \mathrm{C}$. Histamine and $d b c A M P$ stimulated aminopyrine uptakes were 93 (19) and 73 (14) pmol [ $\left.^{4} \mathrm{C}\right]$-aminopyrine/105 cells, respectively. These values were set to $100 \%$. Values are the means (SEM) from three cell experiments with three strains of $\mathrm{H}$ pylori.

PREPARATION OF GASTRIC MEMBRANE VESICLES Gastric membrane vesicles containing $\mathrm{H}^{+} / \mathrm{K}^{+}$ATPase were prepared from pig gastric mucosa as described. ${ }^{8}$ ATPase activity in the material used was $16(0.6) \mu \mathrm{mol} \mathrm{P}_{\mathrm{i}} / \mathrm{mg}$ protein per $\mathrm{h}$ in the presence of $\mathrm{MgCl}_{2}$ alone and 62 (4) $\mu \mathrm{mol} \mathrm{P}_{\mathrm{i}} / \mathrm{mg}$ protein per $\mathrm{h}$ in the presence of $\mathrm{MgCl}_{2}$ plus $100 \mathrm{mM} \mathrm{KCl}$ and the $\mathrm{H}^{+} / \mathrm{K}^{+}$ionophore gramicidin $(25 \mu \mathrm{g} / \mathrm{ml})$.

\section{PROTON TRANSPORT}

Proton transport in membrane vesicles was monitored by the fluorescence quenching of the weak base acridine orange as described. ${ }^{9}$ Membrane protein $(120 \mu \mathrm{g})$ was suspended in $2 \mathrm{ml}$ samples containing $2 \mathrm{mM} \mathrm{MgCl}_{2}, 150$ $\mathrm{mM} \mathrm{KCl}, 10 \mathrm{mM}$ Pipes/Tris buffer ( $\mathrm{pH} 7 \cdot 0)$, and $5 \mu \mathrm{M}$ acridine orange (AO). The test agents were added to the suspension before proton uptake was initiated by ATP (final concentration: $2 \mathrm{mM})$ and valinomycin $(50 \mu \mathrm{M})$.

TABLE I Comparison of inhibitory potency $\left(I C_{50}\right)$ of Helicobacter pylori and fatty acids on histamine-stimulated acid production in isolated and enriched guinea pig parietal cells

\begin{tabular}{ll}
\hline Compound & $I C_{50}$ \\
\hline$H$ pylori & $3 \cdot 2(0 \cdot 07) \times 10^{8}$ bacteria/ml \\
Cis 9,10 -methyleneoctadecanoic acid & $46(13) \mu \mathrm{M}$ \\
Tetradecanoic acid & $308(69) \mu \mathrm{M}$ \\
Hexadecanoic acid & No inhibition \\
Octadecanoic acid & No inhibition
\end{tabular}

Parietal cells $\left(5 \times 10^{5} / \mathrm{ml}\right)$ were preincubated for 20 minutes at $22^{\circ} \mathrm{C}$ with at least five different concentrations of the compounds to be tested. Subsequently, histamine was added and aminopyrine uptake was determined after 40 minute's incubation at $37^{\circ} \mathrm{C}$. $\mathrm{IC}_{50}$ values were obtained from concentration-response curves. Values are means (SEM) from three cell experiments with three different strains of $H$ pylori.
The $\mathrm{K}^{+}$ionophore valinomycin allows entry of $\mathrm{K}^{+}$along with $\mathrm{Cl}^{-}$into the interior of the vesicles where the $\mathrm{K}^{+}$stimulatory site of the enzyme is located. Activation of the ATPase in the presence of $\mathrm{Mg}^{2+}, \mathrm{ATP}, \mathrm{KCl}$, and valinomycin results in proton accumulation inside the vesicles.

\section{ATPASE ACTIVITY}

$\mathrm{H}^{+} / \mathrm{K}^{+}$-ATPase activity was assayed at $37^{\circ} \mathrm{C}$ in $1 \mathrm{ml}$ samples (maintained isosmotic with sucrose) containing $2 \mathrm{mM} \mathrm{MgCl}_{2}, 2 \mathrm{mM}$

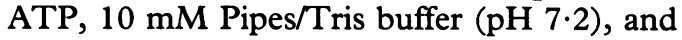
20 or $60 \mu \mathrm{g}$ membrane protein in the absence and presence of $100 \mathrm{mM} \mathrm{KCl}$ and $25 \mu \mathrm{g}$ gramicidin. Gramicidin is a $\mathrm{K}^{+} / \mathrm{H}^{+}$ionophore which allows $\mathrm{K}^{+}$access to the interior of the vesicles but, in contrast to valinomycin, uncouples ATPase activity from the formation of a proton gradient.

Membrane protein was preincubated at $22^{\circ} \mathrm{C}$ with the test agents. After 20 minutes the enzyme reaction was initiated with ATP and it was stopped after 20 minutes $(20 \mu \mathrm{g}$ protein) or five minutes (60 $\mu \mathrm{g}$ protein) incubation by the addition of $1 \mathrm{ml} 1 \mathrm{~N} \mathrm{HCl}$. The amount of inorganic phosphate released from ATP was determined according to Carter and Karl. ${ }^{10}$

\section{PROTEIN DETERMINATION}

Protein was determined according to Lowry et al. ${ }^{11}$

\section{COMPOUNDS}

All chemicals were purchased from Sigma (München, Germany) except pronase E, acridine orange (Merck Darmstadt, Germany) and dibutyryl cyclic AMP (Boehringer Mannheim, Germany). Cis 9,10-methyleneoctadecanoic acid (purity 99\%) was synthesised by $\mathrm{J}$ Holzkamp (Department of Organic Chemistry, University of Hannover, Hannover, Germany).

\section{Results}

EFFECT OF H PYLORI AND FATTY ACIDS ON ACID PRODUCTION IN PARIETAL CELLS As shown in Figure 1, $H$ pylori affected secretagogue stimulated acid production in parietal cells in a biphasic manner. At $10^{7}-10^{8}$ bacteria/ml histamine- and dbcAMP-stimulated acid secretion were enhanced; higher concentrations $\left(>2 \times 10^{8}\right.$ bacteria/ml $)$ progressively inhibited histamine- and dbcAMPstimulated aminopyrine accumulation. In contrast, basal aminopyrine uptake was progressively reduced by the bacteria. Studies with $H$ pylori sonicates and extracts from bacterial culture supernatant gave identical results (data not shown). The fatty acids, cis 9,10-methyleneoctadecanoic acid and tetradecanoic acid inhibited basal, histamine-, and dbcAMP-stimulated aminopyrine uptake in a concentration dependent manner. The $\mathrm{IC}_{50}$ 


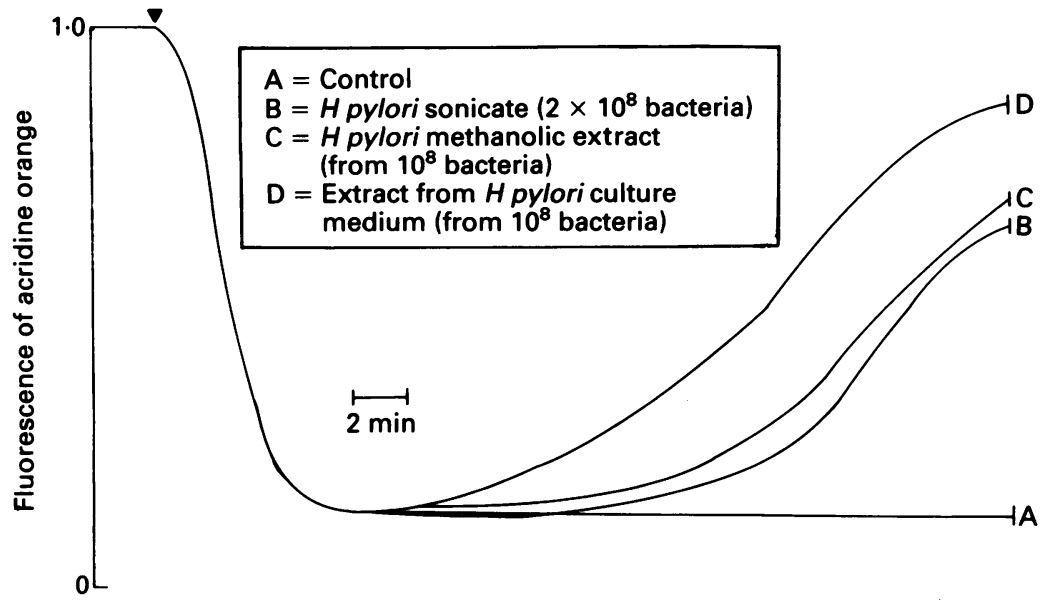

Figure 2: The effect of Helicobacter pylori (sonicate, methanolic extract, extract from culture medium) on $\mathrm{H}^{+} / \mathrm{K}^{+}-A T$ Pase mediated $\mathrm{H}^{+}$uptake in gastric membrane vesicles. $\mathrm{H}$ pylori was added to the vesicles immediately before the pump reaction was started by $A T P$ and valinomycin $(\nabla)$. time dependent dissipation of the $\mathrm{pH}$ gradient (Fig 2). Dissipation of the $\mathrm{pH}$ gradient was prevented by bovine serum albumin (BSA $2 \mathrm{mg}$ ) (data not shown). Heat treatment of the $H$ pylori sonicates at $95^{\circ} \mathrm{C}$ for 30 minutes or treatment with trypsin did not eliminate the inhibitory action on $\mathrm{H}^{+}$uptake (data not shown). The addition of an $H$ pylori sonicate $\left(2 \times 10^{8}\right.$ bacteria) to vesicles in which $\mathrm{H}^{+} / \mathrm{K}^{+}$ATPase reaction had been stopped by EDTA at the steady state level of ATP and valinomycin-induced $\mathrm{H}^{+}$uptake, resulted in an enhanced proton dissipation rate (Fig 3 ). To study the action of intact bacteria on vesicular $\mathrm{H}^{+}$uptake, membrane vesicles $(120 \mu \mathrm{g}$ protein) were coincubated with 1 and $4 \times 10^{8}$ bacteria for two hours at $37^{\circ} \mathrm{C}$ in the proton transport buffer medium. Subsequently, $H$ pylori was separated by centrifugation (8000 $\mathrm{g}$ for five minutes) and $\mathrm{H}^{+}$uptake was initiated. As shown in Figure 4, pretreatment of the gastric membrane vesicles with $H$ pylori resulted in inhibition of $\mathrm{H}^{+}$uptake in response to ATP and ATP plus valinomycin.

Figure 5 shows the effect of different fatty acids produced by $\mathrm{H}$ pylori on $\mathrm{H}^{+}$transport in gastric membrane vesicles. Similar to the action of $H$ pylori, tetradecanoic acid $(25 \mu \mathrm{M})$ and cis 9,10-methyleneoctadeconoic acid (12.5 and $25 \mu \mathrm{M})$ failed to affect the initial rate of acidification but then induced a time dependent dissipation of the established $\mathrm{pH}$ gradient. Proton dissipation was not observed when BSA ( $2 \mathrm{mg}$ ) was present in the medium (data not shown). Hexadecanoic acid and octadecanoic acid $(25 \mu \mathrm{M})$ did not dissipate the acid-interior $\mathrm{pH}$ gradient.

Effects on $\mathrm{H}^{+} / \mathrm{K}^{+}-A T$ Pase activity

$H$ pylori extracts and the four fatty acids inhibited $\mathrm{H}^{+} / \mathrm{K}^{+}$-ATPase activity in gastric membrane vesicles, in a concentration dependent $1 \times 10^{8}$ bacteria), and extracts $H$ pylori culture medium (from $1 \times 10^{8}$ bacteria) had no effect on the initial rate of acidification in gastric membrane vesicles, but induced a

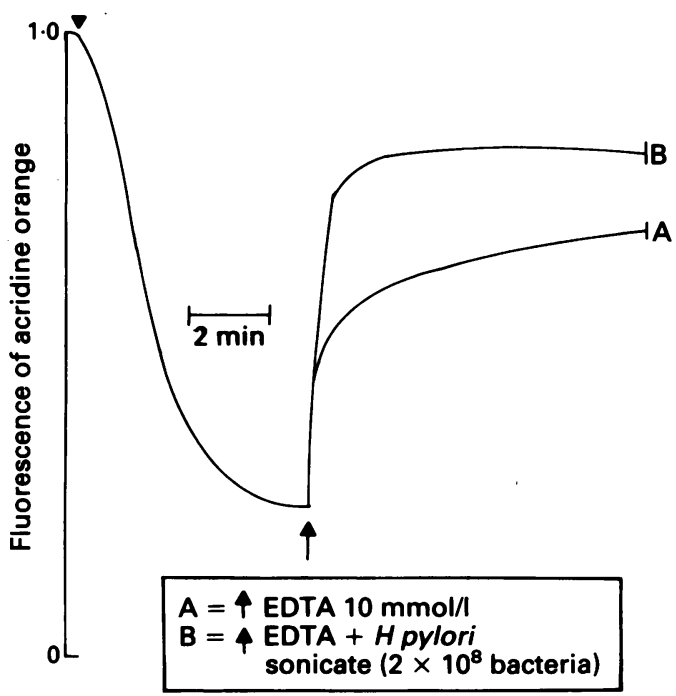

Figure 3: The effect of an Helicobacter pylori sonicate on a preformed $H^{+}$gradient in vesicles in which the ATPase reaction was stopped by the magnesium chelating agent EDTA. EDTA alone (final concentration: $10 \mathrm{mM}$ ) and EDTA together with the Helicobacter sonicate were added as indicated by the arrows.

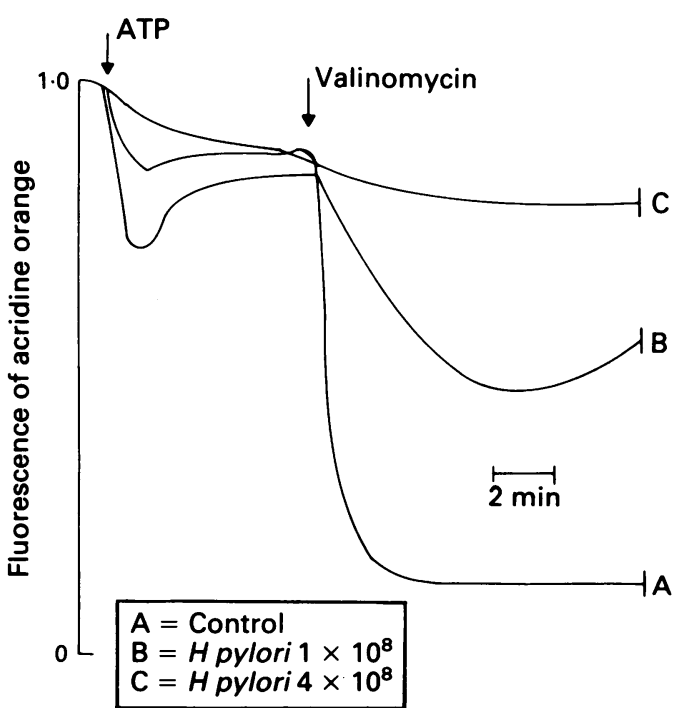

Figure 4: The effect of Helicobacter pylori (intact organisms) on $\mathrm{H}^{+} / \mathrm{K}^{+}-A T$ Pase mediated $\mathrm{H}^{+}$uptake in gastric membrane vesicles. The membrane vesicles were preincubated with $\mathrm{H}$ pylori for two hours at $37^{\circ} \mathrm{C}$. Afterwards the bacteria were separated by centrifugation $\left(8000 \mathrm{~g}, 5\right.$ minutes) and $\mathrm{H}^{+} / \mathrm{K}^{+}-A T$ Pase mediated $\mathrm{H}^{+}$ uptake was initiated by consecutive addition of ATP and valinomycin. 


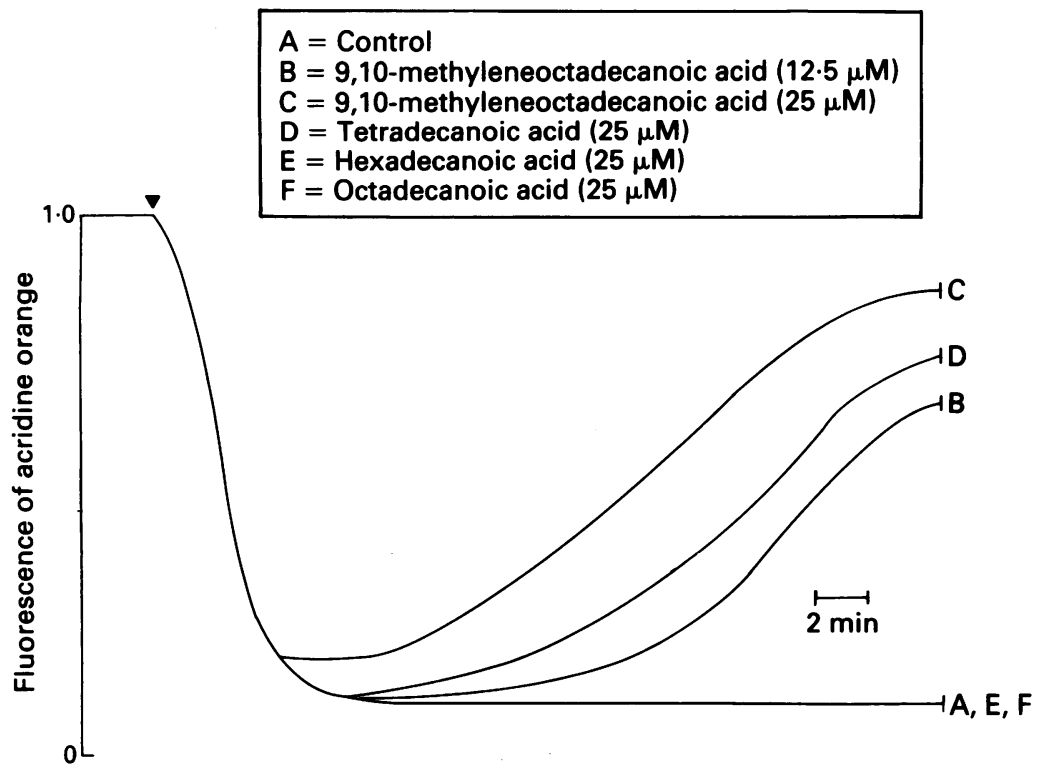

Figure 5: Effect of cis 9,10-methyleneoctadecanoic, tetradecanoic, hexadecanoic and octadecanoic acid on $\mathrm{H}^{+} / \mathrm{K}^{+}$-ATPase-mediated $\mathrm{H}^{+}$uptake in gastric membrane vesicles. The fatty acids were added to the membrane vesicles before the pump reaction was started by $A T P$ and valinomycin ( $\nabla)$.

manner. The inhibitory potency was dependent on the amount of membrane protein in the assay (Table II). At a protein concentration of $60 \mu \mathrm{g} / \mathrm{ml}$ (the proton concentration used in $\mathrm{H}^{+}$transport studies), the effectiveness of the fatty acids in inhibiting $\mathrm{K}^{+}$-stimulated ATPase activity was cis 9,10-methyleneoctadecanoic acid $>$ tetradecanoic acid $>>>$ hexadecanoic acid and octadecanoic acid. The inhibitory action of $H$ pylori extract and the fatty acids on ATPase activity was prevented by BSA (Table II).

\section{Discussion}

We have shown that $H$ pylori and its two major fatty acids, tetradecanoic acid and cis 9,10-methyleneoctadecanoic acid, ${ }^{5}$ inhibit: (i) acid production in isolated parietal cells, (ii) $\mathrm{H}^{+} / \mathrm{K}^{+}$-ATPase activity, and (iii) dissipated $\mathrm{H}^{+}$transport in gastric membrane vesicles.'This finding strongly supports the view that $H$ pylori establishes its antisecretory activity in vitro - that is, in isolated parietal cells - at the $\mathrm{H}^{+}$transporting enzyme system.

As shown in the $\mathrm{H}^{+}$transport studies, $H$ pylori (sonicates, methanolic extracts, and extracts from bacterial culture medium) caused release of $\mathrm{H}^{+}$from the vesicles and

TABLE II Comparison of inhibitory potency $\left(I_{50}\right)$ of Helicobacter pylori extracts and fatty acids on $\mathrm{H}^{+} / \mathrm{K}^{+}-A T$ Pase activity at different vesicular protein concentrations

\begin{tabular}{llcc}
\hline & \multicolumn{3}{l}{ Membrane protein concentration } \\
\cline { 2 - 4 } Compound & $20 \mu g$ & $60 \mu g$ & $60 \mu g+2 m g$ BSA \\
\hline & & & No inhibition at: \\
H pylori (methanolic extract) (bacteria/ml) & $6 \times 10^{6}$ & $8 \times 10^{7}$ & $2 \times 10^{8}$ \\
Cis 9,10-methyleneoctadecanoic acid & $1 \cdot 1 \mu \mathrm{M}$ & $19 \mu \mathrm{M}$ & $100 \mu \mathrm{M}$ \\
Tetradecanoic acid & $3.6 \mu \mathrm{M}$ & $46 \mu \mathrm{M}$ & $100 \mu \mathrm{M}$ \\
Hexcadecanoic acid & $3.6 \mu \mathrm{M}$ & $>>100 \mu \mathrm{M}$ & $100 \mu \mathrm{M}$ \\
Octadecanoic acid & $7 \cdot 2 \mu \mathrm{M}$ & $>>100 \mu \mathrm{M}$ & $100 \mu \mathrm{M}$ \\
\hline
\end{tabular}

Gastric membrane vesicles ( 20 or $60 \mu$ grotein) were preincubated for 20 minutes at $22^{\circ} \mathrm{C}$ with at least four different concentrations of the compounds tested in the absence and presence of 2 $\mathrm{mg}$ bovine serum albumin (BSA). The reaction was initiated by adding ATP and lasted for 20 minutes $\left(20 \mu \mathrm{g}\right.$ protein) or five minutes $\left(60 \mu \mathrm{g}\right.$ protein) at $37^{\circ} \mathrm{C}$. IC ${ }_{50}$ values were obtained from concentration-response curves. Values are means from three different membrane proteins. showed a slow onset of action. An identical action was seen with the fatty acids, tetradecanoic acid and cis 9,10-methyleneoctadecanoic acid. Proton dissipation was not observed when BSA was present in the media. Albumin binds fatty acids. ${ }^{12}$ The identical mode of action of $H$ pylori and both fatty acids in proton transport studies (onset of action, protective effect of BSA) favours the hypothesis that the acid inhibitory factors produced and released by the bacterium are cis 9,10 -methyleneoctadecanoic acid and tetradecanoic acid. Fatty acids contain both charged (carboxyl group) and uncharged (hydrocarbon tail) groups - that is, the molecule has hydrophilic and hydrophobic properties. They could affect $\mathrm{H}^{+} / \mathrm{K}^{+}$-ATPase mediated $\mathrm{H}^{+}$transport by disordering the surrounding membrane lipids (detergent action), or by hydrophobic interaction with the $\mathrm{H}^{+} / \mathrm{K}^{+}$-ATPase. ${ }^{6} \mathrm{~K}^{+}$-stimulated ATPase activity in membrane vesicles was inhibited in a concentration dependent manner by $H$ pylori extracts and the fatty acids tested. Inhibition was prevented by BSA and was dependent on the amount of vesicular protein. This observation suggests that fatty acids and $H$ pylori extracts interfere with hydrophobic sites of the $\mathrm{H}^{+} / \mathrm{K}^{+}$-ATPase and thereby block the catalytic function of the enzyme. The observation that $H$ pylori sonicates enhanced the rate of proton dissipation from membrane vesicles in which the ATPase activity had been stopped by the magnesium chelating agent EDTA, show that $H$ pylori affects $\mathrm{H}^{+} / \mathrm{K}^{+}$-ATPase mediated $\mathrm{H}^{+}$transport not only by blockade of $\mathrm{H}^{+} / \mathrm{K}^{+}$ATPase activity but also by a detergent action.

Recently, Cave et al ${ }^{13}$ postulated that $H$ pylori produces two acid inhibitory factors (AIF 1 and AIF 2). AIF 1 was characterised as a heat labile, pronase-sensitive protein with a molecular weight of approximately 50.000 , and AIF 2 as a probably small and pronaseresistant factor. From the observations made in our study we suggest that AIF 2 are the fatty acids cis 9,10-methyleneoctadecanoic acid and tetradecanoic acid.

An important question is whether the observed mechanism of action of $H$ pylori on acid secretion shown in this in vitro study accounts for its antisecretory action in vivo. The experiments with extracts of bacterial culture medium indicate that sufficient amounts of the acid inhibitor are secreted into the media and coincubation of $H$ pylori (intact organisms) with gastric membrane vesicles resulted in inhibition of ATPase mediated $\mathrm{H}^{+}$ transport. Once in the stomach, $H$ pylori is attached to the mucus layer, to gastric epithelial cells, and is found even within the secretory canaliculi of parietal cells. ${ }^{14}$ The presence of $H$ pylori in this subcellular compartment of parietal cells implies that large quantities of the acid inhibitory factor do not need to be secreted to abolish $\mathrm{H}^{+}$transport at the secretory parietal cell membrane.

Clinical studies, however, have shown that most humans infected with $H$ pylori are not hypochlorhydric and that bacteria induced hypochlorhydria is reversible. ${ }^{15}$ Possible explanations for this phenomenon include 
change in numbers of bacteria or a genetic 'switch off' (down regulation) in the bacterial organism itself. ${ }^{4}$ Our parietal cell experiments showed that $H$ pylori has a dual effect on acid production. At bacterial concentrations ranging from $10^{7}-10^{8}$, secretagogue stimulated aminopyrine uptake was enhanced; higher concentrations inhibited acid production. How $H$ pylori stimulates acid production in parietal cells is not yet known. We have observed no stimulatory effect of an $H$ pylori extract (at low concentrations) on $\mathrm{K}^{+}-(0.5-100 \mathrm{mM})$ or ATP- (0.05-2 mM) induced ATPase activity (W Beil, unpublished results). Recently, König et al ${ }^{16}$ showed that Escherichia coli can activate platelets at an early stimulus transducing event $\left(\mathrm{Ca}^{2+}\right.$-mobilisation, translocation of protein kinase $\mathrm{C})$. Whether $H$ pylori stimulates parietal cell function at this signal transduction level is under investigation.

The skilful technical assistance of Helga Hannemann and Ute Staar is gratefully acknowledged. This work was supported by the Deutsche Forschungsgemeinschaft, Sonderforschungsbereich 280 .

Part of this work was presented at the 94th Meeting of the American Gastroenterological Association in Boston, May 1993, and was published in abstract form (Gastroenterology 1993; 104: A41).

1 Morris A, Nicholson G. Campylobacter pyloridis causes gastritis and raised fasting gastric $\mathrm{pH}$. Am $\mathcal{F}$ Gastroenterol 1987; 82: 192-9.

2 Graham DY, Alpert LC, Smith JL, Yoshimura HH. Iatrogenic Campylobacter pylori infection is a cause of epidemic achlorhydria. Am $f$ Gastroenterol 1988; 83: 974-80.

3 Robert A, Olafsson AS, Lancaster C, Zhang W. Interleukin1 is cytoprotective, antisecretory, stimulates $\mathrm{PGE}_{2}$ synthesis by the stomach and retards gastric emptying. Life Sci 1991; 48: 123-34.

4 Cave DR, Vargas M. Effect of a Campylobacter pylori protein on acid secretion by parietal cells. Lancet 1989; ii: 187-9.

5 Goodwin CS, McCulloch RK, Armstrong JA, Wee SH. Unusual cellular fatty acids and distinctive ultrastructure in a new spiral bacterium (Campylobacter pyloridis) from in a new spiral bacterium (Campylobacter pyloridis) from the humar

6 Im WB, Blakeman DP. Inhibition of gastric $\left(\mathrm{H}^{+}+\mathrm{K}^{+}\right)-$ ATPase by unsaturated long-chain fatty acids. Biochim Biophys Acta 1982; 692: 355-60.

7 Sewing K-Fr, Harms P, Schulz G, Hannemann H. Effect of substituted benzimidazoles on acid secretion in isolated and enriched guinea pig parietal cells. Gut 1983; 24: 557-60.

8 Beil W, Starr U, Schünemann P, Sewing K-Fr. Omeprazole, SCH 28080 and doxepin differ in their characteristics to inhibit $\mathrm{H}^{+} / \mathrm{K}^{+}$-ATPase driven proton crumulation by parietal cell membrane vesicles. Biochen accumulation by parietal cell mem

9 Lee HC, Forte JG. A study of $\mathrm{H}^{+}$transport in gastric microsomal vesicles using fluorescent probes. Biochim Biophys Acta 1978; 508: 339-56.

10 Carter SG, Karl DW. Inorganic phosphate assay with malachite green: An improvement and evaluation. f Biochem Biophys Methods 1982; 7: 7-13.

11 Lowry OH, Rosebrough NJ, Farr AL, Randall RJ. Protein measurement with the folin phenol reagent. $f$ Biol Chem 1951; 193: 265-75.

12 Spector AA, Fletcher JE, Ashbrook JD. Analysis of longchain free fatty acid binding to bovine serum albumin by determination of stepwise equilibrium constants. Biochemistry 1971; 10: 3229-32.

13 Cave DR King Ww, Hoffman IS Production of two chemically distinct acid-inhibitory factors by Helicobacter pylori. European fournal of Gastroenterology and Hepatology pylori. European fournal of

14 Chen XG, Correa P, Offerhaus J, Rodriguez E, Janney F, Hoffmann E, Fox J, Hunter F, Diavolitis S. Ultrastructure of the gastric mucosa harboring Campylobacter-like organisms. Am f Clin Pathol 1986; 86: 575-82.

15 Rademaker JW, Hunt RH. Helicobacter pylori and gastric acid secretion: The ulcer link? Scand $f$ Gastroenterol 1991 26 (suppl 187): 71-7.

16 König B, Schönfeld W, Scheffer J, König W. Signal transduction in human platelets and inflammatory mediator release induced by genetically cloned hemolysinpositive and -negative Escherichia coli strains. Infect positive and -negative Esch 